\title{
Students' Satisfaction with the Library, Familial Reading Environments, and Reading Attitudes in Structural Equation Modeling Analyses
}

\author{
Li-Yun Chang \\ The teacher and reader service group leader \\ Doctoral Student of Institute of Education \\ Taiwan \\ Chao-Chi Yeh \\ Director of Student Affairs Division \\ Doctoral Student \\ Taiwan
}

The main purpose of this study was to test the fit of model of the relationships among students' satisfaction with the library, familial reading environments and whose reading attitudes. Further, it tried to find out whether the familial reading environments and satisfaction with the library affect the students' reading attitudes, and then explored the direct, indirect and total effects between the students' satisfaction with the library, familial reading environments, and reading attitudes.

The participants of this study included 714 high school students (356 male, 358 female), and the findings suggested that (1) the theoretical model of students' satisfactions with the library, familial reading environments, and reading attitudes using Structural Equation Modeling was supported;(2) students' satisfactions with the library were in connection with their familial reading environments; (3) students' satisfactions of library and familial reading environments had a significantly positive effect on students' reading attitudes.

Key words: reading attitude; familial reading environment; satisfaction with the library; structural equation modeling

\section{Introduction}

The TIMSS \& PIRLS International Study Center (2007) released of the PIRLS 2006 results. PIRLS 2006 is a comparative study of student achievement in reading literacy conducted in 40 countries. The highest achieving participants in PIRLS 2006 represented different regions of the world geographically, including Eastern Europe (the Russian Federation, Hungary, and Bulgaria), Asia (Hong Kong SAR and Singapore), Canada (Alberta, British Columbia, and Ontario), Italy in Southern Europe, Western Europe (Luxembourg, Germany, the Netherlands, and Belgium (Flemish), and Scandinavia (Sweden and Denmark). Taiwan was much inferior to Hong Kong in reading literacy, which deserved our concern because reading literacy should be the essential ability of our children facing the international challenge and future vicissitude.

Children's interests and attitudes were main considerations in enticing children to enter the world of books. Reading attitude might be defined as a disposition that responds in a favorable or unfavorable manner in relation to reading (Swalander \& Taube, 2007). Many studies showed that good reading attitude positively affects 
reading behavior (Stokmans, 1999; Swalander \& Taube, 2007), and that good readers have a more positive attitude than poor readers toward reading (WigWeld \& Asher, 1984). The effect of reading attitude on reading behavior is mainly attributable to the effect of enjoyment aspect (Stokmans, 1999). Therefore, the familial reading environment and the school library environment to reading attitude could yield tremendous influence. McQuillan and Conde (1996) proposed that texts for pleasure reading or interest reading provided more flow. Fiction was more likely to produce flow than nonfiction, and texts which provided flow gave the reader personal or intellectual benefits.

Children who grew up in families with many books and whose parents spent a lot of time on reading and writing seldom develop problems with literacy in school (McQuillan \& Conde, 1996; Snow, Burns, \& GriYn, 1998). That is to say, a majority of reading problems falls upon children from poor families with little education (Snow et al., 1998). Some parents provide many opportunities for their children to develop a favorable attitude toward reading; others do not. Children are likely to have a favorable attitude toward subjects they find it interesting and dislike one that is not interesting. People around children generally influence their attitudes. Parents who enjoyed reading tended to pass these attitudes on to children, and influence the attitudes and behaviors toward reading of their children (Harris \& Sipay, 1990; Purcell-Gates, 1996; Richards, 1991). Researchers have concluded, that the single most important factor for predicting reading ability is the number of books in the household (Swalander \& Taube, 2007).

Programme for International Student Assessment (PISA) had shown that there are considerable differences in reading ability between students from high SES and student from low SES families (OECD, 2001). High attitude scores and good reading behavior are closely related to students having parents with a higher educational status, coming from a more culturally enriched familial environment and receiving more support for school work (van Schooten, de Glopper, \& Stoel, 2004). In addition, having sufficient mental and physical resources were a requisite to the intention to engage in reading activities, so they could affect the attitude towards reading and reading behavior (Miesen, 2003). Worthy, Moorman and Turner (1999) investigated reading preferences and found the light materials (scary series books, comics, and magazines) that topped the list for every sub-group students. There was very limited availability of preferred materials in schools, so the most students obtained reading materials from purchased sources rather than from school libraries.

Netherland(2004)compared students and parents in Title-I and Non-Title I schools, and found that students and parents in Title I schools were less likely to read at home for enjoyment, use the public library, or read magazines and newspapers. Results demonstrated that students and parents in Title I schools, overall, read less than students and parents in Non-Title I schools, and reported having fewer books of their own and fewer educational materials at home.

The pattern of reading, as was known from the past, may not be the same as it today or in the future. Research in reading habits is needed to include current advancement in Information Communication Technology (ICT), where the technology has enabled reading to be more timely and somewhat non-linear by using devices such as computers, PDAs and wireless phones without the presence of any printed document. Karim and Hasan (2007) find that the web site was seen as an increasingly important reading source. So the resources equipment of school library could influence students' reading.

Another project designed by a high school librarian, Bliss, used a recorded reading 
program and achieved impressive results. The seventh through twelfth grade students were required to spend one hour per school day in a reading lab. They became more confident as they learned that their slow reading was due to lack of practice, and their teachers reported that they had better academic performance.

Libraries are ideal places to find books and spend time in reading (Richards, 1991). Mean scores of students' attitudes toward the library and reading were significantly positive (Kreiser, 1991). Children with higher reading attitude scores attended more library programs and visited the library more often(Richards, 1991). In addition, significant differences exist between different types of reading materials, especially traditional reading materials and those on web sites (Karim and Hasan, 2007).

Therefore, it is important for students to develop positive reading attitude because it affects their reading behavior. And there is a lot of support for the assumption that children growing up in a literacy rich environment where a positive value is ascribed to literacy will develop a positive attitude towards reading, which in turn will lead to good reading ability and positive thoughts about themselves as well in the reading situation. Since the library has a good environment for reading, it is reasonable to assume that there may be some relationships between students' attitudes toward the library and their reading attitudes.

The purposes of this study were threefold: (a) to test the fit of the theoretical model of the relationships among students' satisfaction with the library, familial reading environments and whose reading attitudes; (b) to find out whether the familial reading environments and satisfaction with the library affect students' reading attitudes; (c) to explore the direct, indirect and total effect between the independent and dependent variables.

\section{Method}

\section{Participants}

Participants in this study were 781high school students from Nantou Shiu Kuang High School in Taiwan. However, only 714 (356 male, 358 female) complete the questionnaires. The composition of the participants was as follows: 528 junior high school students ( $74 \%$ ), and 186 senior high school students (26\%). The mean age of participants was 14.7 years old, falling between 13 and 18 years old. The researchers went to each class to administer the questionnaires at a prearranged time. The time for finishing answer the questionnaire was about 20 minutes.

\section{Instrumentation}

The questionnaire used in this study composed four sections, including demographics information, reading attitudes, familial reading environments, and students' satisfaction with the library. For demographic information section, students were asked to report their gender, age, and to provide information regarding their mother and father's occupation and educational status. For reading attitudes, students completed 17 items which includes happy reading ( 6 items), active reading (5 items), reading harvest (3 items), and reading leisure (3 items). For familial reading environments, students completed 17 items including discussion and sharing with others ( 5 items), subscription to books and periodicals ( 5 items), reading books and periodicals (5 items), value reading ( 2 items). For students' satisfaction with the library, students completed 17 items including library service (5 items), using 
education ( 1 items), resources equipment ( 7 items), and library environment (4 items).

The instruments adapted from two sources: Hsieh (2003) and China Tsing Hua University Books Intelligence Committee (2004), but some revisions were made to meet the needs of this study. Each item was rated on a 4-point Likert scale ranging from 1 (strongly disagree) to 4 (strongly agree). Cronbach's $\alpha$ coefficients of satisfactions with the library, familial reading environments, and reading attitudes were .89, .90, and .93.(see Table 1)

\section{Statistical Analyses}

Using the SPSS and the AMOS software, the data were analyzed by several statistical methods stated below.

Item analyses, factor analyses, and Cronbach's $\alpha$ coefficients were used to exam reliability and validity of the questionnaires on the pretest. Mean, standard deviation, and correlation were used on the 12 observed variables. The analyses were conducted on covariance matrices, and the solutions were generated on the basis of maximum-likelihood estimation. Confirmatory Factor Analyses examined the theoretical model (Figure 1), which designated that the items for each factor loadings on their respective latent variables. And further, it tried to find out whether the familial reading environments and satisfaction with the library affect the students' reading attitudes, and then explored the direct, indirect and total effect between the independent and dependent variables.

\section{Model Evaluation Criteria}

In SEM, the degree of correspondence between any particular model and the data can be assessed with the use of several goodness-of-fit indexes. We evaluated models using the comparative fit index (CFI) (Bentler, 1990; Hu \& Bentler, 1999), three Tucker-Lewis index (TLI)(Bentler \& Bonett,1980), the goodness-of fit index (GFI), the root-mean-square error of approximation (RMSEA) (Hu \& Bentler, 1999), the normed chisquare (NC) (Jöreskog, 1970) and the critical N(CN) (Hoelter, 1983; Yu, 2006). According to the study by $\mathrm{Hu} \&$ Bentler (1999), value of .95 or above for the CFI, GFI and value of RMSEA of .06 or small indicate good fit. In addition, value of above 1.0 and below 5.0 for the $\mathrm{NC}(\mathrm{Yu}, 2006)$ and value of 90 or bigger for the TLI (Bentler, 1990) indicate good fit.

Table 1

The item number and Cronbach a Coefficients of latent variables and observed variables

\begin{tabular}{|c|c|c|c|c|}
\hline $\begin{array}{l}\text { Observed } \\
\text { variables }\end{array}$ & Cronbach $\alpha$ & $\begin{array}{l}\text { Total item } \\
\text { numbers }\end{array}$ & Observed variables & $\begin{array}{c}\text { The numbers of } \\
\text { items }\end{array}$ \\
\hline \multirow{4}{*}{$\begin{array}{l}\text { Satisfactions } \\
\text { with library }\end{array}$} & .89 & 17 & Library service & 5 \\
\hline & & & Using education & 1 \\
\hline & & & Resources equipment & 7 \\
\hline & & & Library environment & 4 \\
\hline \multirow[t]{2}{*}{$\begin{array}{l}\text { Familial reading } \\
\text { environments }\end{array}$} & .90 & 17 & Discussion and share & 5 \\
\hline & & & Subscription books & 5 \\
\hline
\end{tabular}




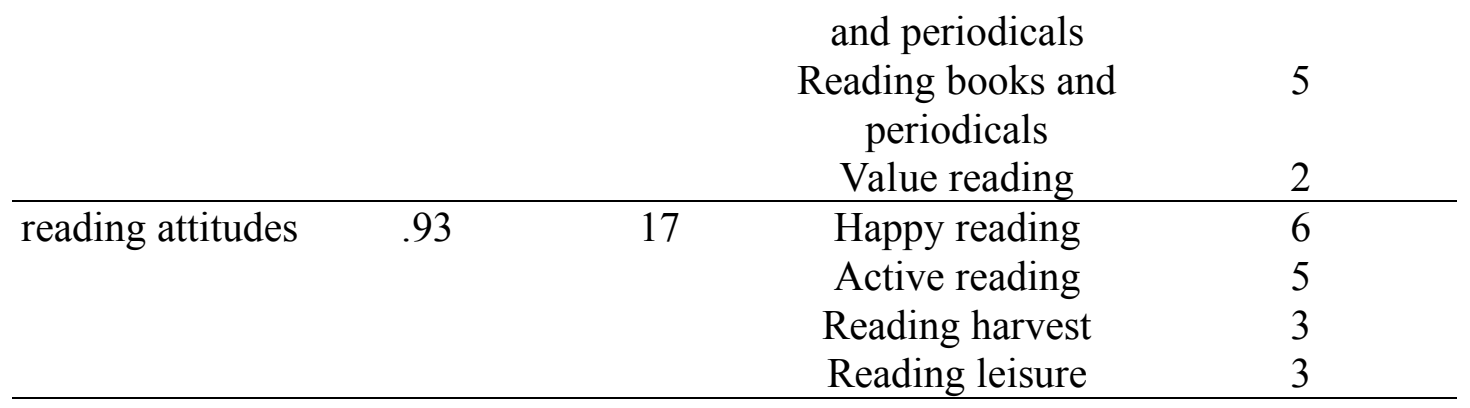

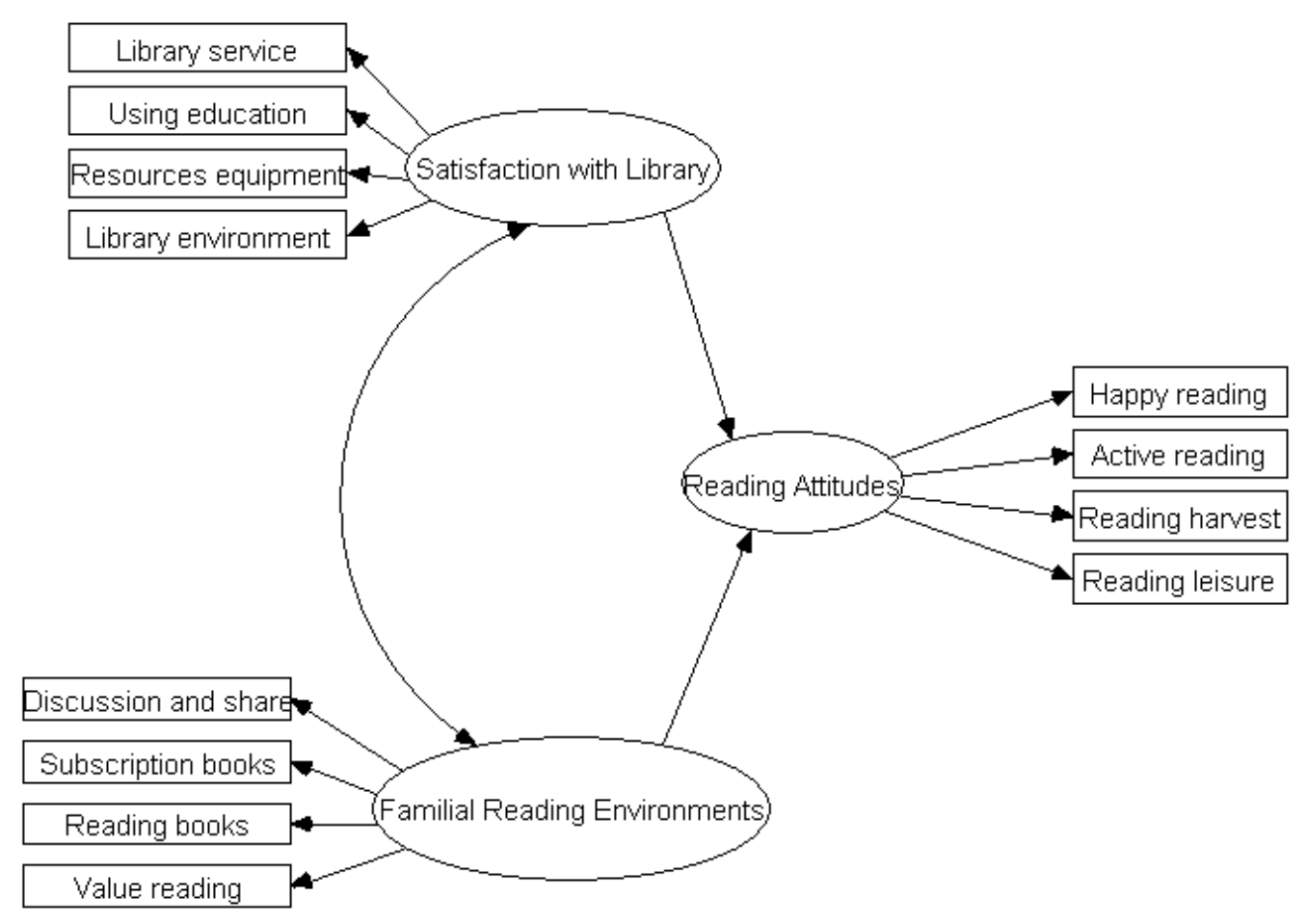

Figure1 The theoretical model of satisfaction with the library, familial reading environments and their reading attitudes

\section{Results and Discussion}

\section{Descriptive Statistics}

Means, standard deviations, and correlation for twelve observed variables are displayed in Table 2. Because the maximum likelihood estimation procedures used in this study can produce distorted result when the normality assumption is severely violated (Curran, West and Finch, 1996), the normality of each variable was investigated in terms of its skewness and kurtosis. In addition, the skew of this study was from 0.05 to 1.1 and the kurtosis was from 0.04 to 1.2. Curran et al (1996) proposed that absolute values of skew index greater than 2.0 and kurtosis index greater than 7.0 indicate serious departures from normality. So, the normality assumption of all the variables was well met. The results of the correlation analyses showed that all variable are highly correlated. 
Table 2

Mean, standard deviation, and correlation coefficients of 12 observed variables

\begin{tabular}{|c|c|c|c|c|c|c|c|c|c|c|c|c|}
\hline & 1 & 2 & 3 & 4 & 5 & 6 & 7 & 8 & 9 & 10 & 11 & 12 \\
\hline 1.happy reading & 1 & & & & & & & & & & & \\
\hline 2.active reading & $.75 * * *$ & 1 & & & & & & & & & & \\
\hline 3.reading harvest & $.64 * * *$ & $.65^{* * *}$ & 1 & & & & & & & & & \\
\hline 4.reading leisure & $.57 * * *$ & $.61 * * *$ & $.42 * * *$ & 1 & & & & & & & & \\
\hline $\begin{array}{l}\text { 5.discussion and } \\
\text { share }\end{array}$ & $.26^{* * *}$ & $.33 * * *$ & $.24 * * *$ & $.32 * * *$ & 1 & & & & & & & \\
\hline $\begin{array}{l}\text { 6.subscription books } \\
\text { and periodicals }\end{array}$ & $.31 * * *$ & $.35 * * *$ & $.27 * * *$ & $.38 * * *$ & $.74 * * *$ & 1 & & & & & & \\
\hline $\begin{array}{l}\text { 7.reading books } \\
\text { and periodicals }\end{array}$ & $.16^{* * *}$ & $.22 * * *$ & $.15^{* * *}$ & $.25 * * *$ & $.65 * * *$ & $.70 * * *$ & 1 & & & & & \\
\hline 8.value reading & $.22 * * *$ & $.26 * * *$ & $.26^{* * *}$ & $.24 * * *$ & $.47 * * *$ & $.50 * * *$ & $.47 * * *$ & 1 & & & & \\
\hline 9.library service & $.22 * * *$ & $.21 * * *$ & $.29 * * *$ & $.18^{* * *}$ & $.20 * * *$ & $.21 * * *$ & $.22 * * *$ & $.29 * * *$ & 1 & & & \\
\hline 10.using education & $.20 * * *$ & $.18 * * *$ & $.23 * * *$ & $.15 * * *$ & $.21 * * *$ & $.17 * * *$ & $.19^{* * *}$ & $.24 * * *$ & $.59 * * *$ & 1 & & \\
\hline $\begin{array}{l}\text { 11.resources } \\
\text { equipment }\end{array}$ & $.27 * * *$ & $.26 * * *$ & $.31 * * *$ & $.18 * * *$ & $.20 * * *$ & $.21 * * *$ & $.21 * * *$ & $.26 * * *$ & $.74 * * *$ & $.62 * * *$ & 1 & \\
\hline $\begin{array}{l}\text { 12.library } \\
\text { environment }\end{array}$ & $.22 * * *$ & $.20 * * *$ & $.25 * * *$ & $.15^{* * *}$ & $.11 * *$ & $.11^{* *}$ & $.12 * *$ & $.20 * * *$ & $.67^{* * *}$ & $.53 * * *$ & $.77 * * *$ & 1 \\
\hline M & 2.97 & 2.84 & 3.12 & 2.61 & 2.28 & 2.34 & 2.46 & 2.69 & 3.14 & 3.22 & 3.15 & 3.31 \\
\hline SD & .60 & .64 & .63 & .78 & .75 & .78 & .69 & .70 & .63 & .85 & .65 & .63 \\
\hline skewness & -.34 & -.19 & -.41 & -.05 & .19 & .07 & -.12 & -.34 & -.83 & -.84 & -.74 & -1.12 \\
\hline kurtosis & -.09 & -.43 & -.32 & -.74 & -.73 &.-.70 & -.45 & -.04 & .72 & -.13 & .21 & 1.23 \\
\hline
\end{tabular}

$* * \mathrm{p}<.01 ; * * * \mathrm{p}<.001$

\section{Fit statistics for Theoretical Model}

The model that was tested is presented in Figure 1. Presented in Table 3 are the fit indices for measurement model and theoretical model. The indices of the theoretical model showed a good fit. Although the chi-square was significant, the NC, GFI, RMSEA, TLI, CFI and CN indicated good fit. The factor loadings for the reading attitudes were .85 for happy reading, .89 for active reading, .73 for reading harvest, and .67 for reading leisure. The satisfactions of library were .81 for library service, .68 for using education, .93 for resources equipment, and .82 for library environment. The familial reading environments were .83 for discussion and share, .89 for subscription to books and periodicals, .77 for reading books and periodicals, and .57 for value reading.

In terms of measurement model, the factor loading and measurement errors of the12 observed variables showed statistical significance $(p<.001)$. The results meant 
that the questionnaire items could represent its latent variables. That is this questionnaire items have a good validity. The composite reliabilities of the three latent variables of reading attitudes, satisfaction with the library, and familial reading environments were .94, .92, and .93, which indicate ideal composite reliabilities. These accorded with Bagozzi and Yi (1988) who proposed that ideal composite reliability $\left(\rho_{c}\right)$ must be above .60. The average variance extracted index $\left(\rho_{v}\right)$ was $.79, .75$, and .78 , which accorded with Fornell and Larcker (1981) who proposed that the index must be above .50. That is, the indicators for the latent variables explained the variance far more than was explained by the measuring error, so the indicators could represent the latent variables.

In terms of structural model, the satisfaction with the library and the familial reading environment latent constructs were positively correlated with one another $(r=.27, p<.001)$. The standardized regression weights from the satisfaction with the library to the reading attitude latent constructs was .24 $(p<.001)$, and the familial reading environment to the reading attitude latent constructs was $.36(p<.001)$. The squared multiple correlation of endogenous variable, reading attitude, was .23. The results represented that the structural model of the theoretical model had a good fit.

Table 3

Fit indices for measurement model and theoretical model

\begin{tabular}{|c|c|c|c|c|c|}
\hline Index name & $\begin{array}{l}\text { The fit of the } \\
\text { judgement } \\
\text { value }\end{array}$ & $\begin{array}{l}\text { Measurement } \\
\text { model A } \\
\text { (satisfaction } \\
\text { with the } \\
\text { library) }\end{array}$ & $\begin{array}{l}\text { Measurement } \\
\text { model } \\
\mathrm{B} \text { (familial } \\
\text { reading } \\
\text { environments) }\end{array}$ & $\begin{array}{l}\text { Measureme } \\
\text { nt } \\
\text { modelC(rea } \\
\text { ding } \\
\text { attitudes) } \\
\end{array}$ & $\begin{array}{l}\text { theoretical } \\
\text { model }\end{array}$ \\
\hline$\chi^{2}$ & $\begin{array}{l}\text { Non } \\
\text { significant } \\
(p>.05)\end{array}$ & $\begin{array}{r}13.018 \\
(\mathrm{df}=2 \\
\mathrm{p}=.001)\end{array}$ & $\begin{array}{l}2.126(\mathrm{df}=2 \\
\mathrm{p}=.345)\end{array}$ & $\begin{array}{l}16.512(\mathrm{df}=2 \\
\mathrm{p}=.000)\end{array}$ & $\begin{array}{l}162.806(\mathrm{df}= \\
51, \mathrm{p}=.000)\end{array}$ \\
\hline GFI & $>.95$ & .991 & .998 & .989 & .963 \\
\hline SRMR & $<.05$ & .017 & .008 & .022 & .049 \\
\hline RMSEA & $<.06$ & .088 & .009 & .101 & .055 \\
\hline TLI & $>.90$ & .980 & 1.000 & .969 & .969 \\
\hline CFI & $>.95$ & .993 & 1.000 & .990 & .976 \\
\hline $\mathrm{NC}$ & $1<\mathrm{NC}<5$ & 6.509 & 1.063 & 8.256 & 3.192 \\
\hline Hoelter & $>200$ & 329 & 2010 & 259 & 301 \\
\hline
\end{tabular}

\section{The effect from independent to dependent variable}

The direct effect for the satisfaction with the library to the reading attitude was .24, indirect effect was .10, and the total effect was .34. That is, the more the satisfaction with the library and the better familial reading environment students have, the better reading attitudes students gain. The direct effect for the familial reading environment to the reading attitude was .36 , indirect effect was .08 , so the total effect was .43 . These findings are consistent with Kreiser's (1991) study in which student attitudes toward the library was positively correlated with student attitudes toward reading. In addition, Harris, and Sipay (1990), Purcell-Gates (1996), Richards (1991) have similar findings that parents who enjoyed reading tended to pass these attitudes on to children. 


\section{Conclusion}

In conclusion, several research questions were addressed in this study, and the principal findings suggested that (1) the theoretical model of students' satisfactions with the library, familial reading environments, and reading attitudes using Structural Equation Modeling was supported;(2) students' satisfactions with the library were in connection with their familial reading environments; (3) students' satisfactions of library and familial reading environments had a significantly positive effect on students' reading attitudes.

\section{Reference}

Bagozzi, R. P., \& Yi, Y. (1988). On the evaluation of structural equation model. Academic of Marketing Science, 16, 76-94.

Bentler, P. M. (1990). Comparative fit indexes in structural models. Psychological Bulletin, 107, 238-246.

Bentler, P. M., \& Bonett, D. G. (1980). Significance tests and goodness of fit in the analysis of covariance structure. Psychological Bulletin, 88, 588-606.

Cheung, G. W., \& Rensvold, R. B. (2002). Evaluating goodness-of-fit index for testing measurement invariance. Structure Equation Modeling, 9, 233-255.

China Tsing Hua University books intelligence committee (2004). Library reader degree of satisfaction report of investigation. Retrieved August 20, 2007, from http://infoweb.lib.tsinghua.edu.cn/Query/ abstractreport 2004 .pdf

Curran, P. J., West, S, G., \& Finch, J. F (1996). The robustness of test statistics to nonnormality and specification error in confirmatory factor analysis. Psychological Methods, 1, 16-29.

Fornell, C., \& Larcker, D. F. (1981). Evaluating structural equation models with unobservable variables and measurement error. Journal of Marketing Research, 18(3), 39-50.

Giles, V. M. (2005). Secondary school students' (grades 7--12) attitudes toward reading motivational activities. Ed.D., University of Houston.

Harris, A. J., \& Sipay, E. R. (1990). How to increase reading ability. A guide to developmental and remedial methods. New York: Longman.

Hoelter, J. W. (1983). The analysis of covariance structure: Goodness-of-fit indices. Sociological Methods and Research, 11, 325-344.

Hsieh, M. P. (2003). Research on the Relationship between Reading Attitudes, Home Literacy Environment, Reading Comprehension Ability among Elementary School Students. MEd, National Ping Tung University of Education, 091NPTT1576028

Hu, L. T., \& Bentler, P. M. (1999). Cutoff criteria for fit indexes in covariance structural equation modeling: Conventional criteria versus new alternatives. Structural Equation Modeling, 6(1), 1-55.

Jöreskog, K. G.. (1970). A general method for analysis of covariance structure. Biometrika, 57, 239-251.

Karim, N..S.A. \& Hasan, A.(2007). Reading habits and attitude in the digital age - Analysis of gender and academic program differences in Malaysia. Electronic Library. 25, 285-298.

Kreiser, J. L. C. (1991). A comparative study of curriculum integrated and traditional school library media programs: Fifth-grade students' reading and media program attitudes and utilization. Ed.D., Kansas State University, AAT 9218617.

Li, M. N.(2006). An Introduction to Amos and Its Uses in Scale Development: Graphics \& Basic. Taipei: Psychological Publishing Co.

McQuillan, J. \& Conde, G.(1996). The Conditions of Flow in Reading: Two Studies of Optimal Experience. Reading Psychology, 17(2),109-135.

Miesen, H. W. J. M.(2003). Predicting and explaining literary reading: an application of the theory of planned behavior. Poetics. 31, 189-212. 
Organisation for Economic Co-operation and Development. (2001). Knowledge and skills for life: First results from the OECD Programme for International Student Assessment (PISA) 2000. Paris: OECD.

Purcell-Gates, V. (1996). Stories, coupons, and the TV-guide: Relationship between home literacy experiences and emergent literacy knowledge. Reading Research Quarterly, 31, 406-428.

Richards, V. (1991). Learning Disabled Children's Attitudes toward Reading and Libraries. Dissertations/Theses - Masters Theses, Kent State University. (ED352960)

Snow, C. E., Burns, M. S., \& GriYn, P. (Eds.). (1998). Preventing reading diYculties in young children. Washington, DC: National Academy Press.

Stokmans, M. J.W. (1999). Reading attitude and its effect on leisure time reading. Poetics, 26, 245-261.

Swalander, L., \& Taube, K. (2007). Influences of family based prerequisites, reading attitude, and self-regulation on reading ability. Contemporary Educational Psychology, 32, 206-230.

The TIMSS \& PIRLS International Study Center. (2007). PIRLS 2006 International Report. Retrieved January 20, 2008, from http://timss.bc.edu/pirls2006/intl_rpt. Html

van Schooten, E., de Glopper, K., \& Stoel, R. D. (2004). Development of attitude toward reading adolescent literature and literary reading behavior. Poetics, 32, 343-386.

WigWeld, A., \& Asher, S. R. (1984). Social and motivational inXuences on reading. In P. D. Pearson, R. Barr, M. L. Kamil, \& P. Mosenthal (Eds.), Handbook of reading research (pp. 423-452). New York: Longman.

Worthy, J., Moorman, M., \& Turner, M. (1999). What Johnny Likes to Read Is Hard To Find in School. Reading Research Quarterly, 34(1), 12-27.

Yu, M. N.(2006). Latent Variable Models: The Application of SIMPLIS (p124-125). Taipei: Higher Education.

\section{Biographical Notes}

Since 1998, I have served in Shiuh kuang Senior High School to be a teacher. The working experience offered me a good chance to explore the reading attitude of student. In 1995 I was admitted by National Taiwan Normal University to pursue a master degree in Health Education. I developed several professional interests in sexual education, action research. And then, in 2006 I was admitted by National Changhua University of Education to be a student of $\mathrm{PhD}$ program and major in education.

\section{Statement of Originality}

This statement certifies that the paper above is based upon original research undertaken by us and that the paper was conceived and written by us alone and has not been published elsewhere. All information and ideas from others is referenced. 